\title{
O teatro das quimeras: um estudo das fronteiras entre o homem e o animal na obra de Valère Novarina
}

Milla Benicio Ribeiro de Almeida

Recebido em 15/06/2011 - Aprovado em 10/09/2011

\section{Resumo}

O presente artigo dedica-se à reflexão proposta por Valère Novarina sobre os limites do homem, compreendendo seu teatro como uma encenação da linguagem, e, portanto do humano, com metáforas densas, criadas sob a "máscara do animal", que se prestam à constituição do conflito entre homem e mundo. Encenar a animalidade, nesse contexto, não significa, pois, tornar o palco lugar da imitação ou da representação, mas antes um espaço para questioná-las. Novarina revê, destarte, toda uma tradição metafísica, presente no teatro, mas também no pensamento. Propomo-nos, assim, a percorrer esse mesmo caminho, se quisermos compreender a amplitude da escrita novariniana e suas implicações poéticas e filosóficas. $\mathrm{O}$ animal do tempo é a obra que elegemos para fazer convergir uma tal análise.

Palavras-chave: Novarina; representação; teatro; animalidade; metafísica. 
A animalidade é uma das manifestações mais radicais da alteridade. O princípio de incerteza que rege esse imaginário vincula-se metaforicamente a quase todo comportamento humano tido como incompreensível, anormal, obsceno. Segundo Jean Baudrillard, a lógica da animalidade é aquela "da exclusão, da reclusão, da discriminação e [...] faz com que toda a sociedade acabe por alinhar [essa lógica] pelos axiomas da loucura, da infância, da sexualidade e das raças inferiores" (BAUDRILLARD, 1991, p. 167).

Conforme uma segunda interpretação etimológica da palavra "obsceno", essa alteridade apresenta-se também como algo que está fora de cena. De fato, o animal foi deposto da cena filosófica nos últimos três séculos em nossa sociedade ocidental, mas resgatado com frequência pelo pensamento poético e literário, fazendo vigorar neste movimento uma outra linguagem para além da função utilitarista e taxionômica à qual a fala corrente vinculou-se na modernidade.

Sob os signos estabelecidos e apesar deles, [o poeta] ouve um outro discurso, mais profundo, que lembra o tempo em que as palavras cintilavam na semelhança universal das coisas: a Soberania do Mesmo, tão difícil de enunciar, apaga na sua linhagem a distinção dos signos. Daí sem dúvida, na cultura ocidental moderna, o face-a-face da poesia e da loucura. (FOUCAULT, 2010, p. 68)

Interessa-nos aqui pesquisar em que medida o teatro de Valère Novarina põe esse embate em cena, como ele encena a seu próprio modo a tensão entre poesia e filosofia, instinto e racionalidade, loucura e linearidade, escuta e fala, tendo como palco a linguagem. $\mathrm{O}$ encontro entre teatro e reflexão filosófica não é, entretanto, inédito: questões ligadas ao mimetismo e à representação são fundadoras em ambos os campos, e a relação entre esses dois conceitos terá um papel relevante na definição do que é realidade em diferentes momentos na história do pensamento humano.

É talvez por esse motivo que a própria noção de teatro traga em si um traço fortemente metafórico e tão logo se vincule à atividade de pensar: tal conceito "ilumina tanto o caráter teatral da filosofia quanto a interpretação metafísica da mímesis em geral" (NASCIMENTO, 1999, p. 76). Assim, desde o teatro aristotélico até a crueldade artaudiana - dois extremos de uma mesma tradição teatral e filosófica - são devedores da representação metafísica, seja pelo reforço na esfera artística de seu posicionamento teórico ou pelo mais radical rompimento com essa mesma tradição.

Busquemos, portanto, aprofundarmo-nos na - jamais estável - dinâmica existente entre imitar e representar para compreendermos não apenas as mudanças operadas ao longo dos séculos no modo de apreendermos o mundo, mas por que 
"a metafísica da presença em sua modalidade visual (aparência/ essência, cópia/modelo, imagem superficial/realidade profunda...) é fortemente tributária do logocentrismo" (NASCIMENTO, 1999, p. 66), uma herança filosófica refutada em seus dois pólos, primazia da visão e da linguagem verbal, por Antonin Artaud e suas crias, dentre eles, ironicamente, Valère Novarina e seu teatro das palavras.

Segundo Michel Foucault, até o século XVI, o mundo se oferecia ao homem como linguagem cifrada, e ela própria ao mundo pertencia. A semelhança desempenhou, nesse contexto, um papel crucial no movimento de representação: "teatro da vida ou espelho do mundo, tal era o título de toda linguagem, sua maneira de anunciar-se e de formular seu direito de falar". (FOUCAULT, 2010, p. 23) As analogias eram então fecundas e infinitas, tendo como única limitação seu ponto comum de partida e de chegada: o ser humano, termo central onde as relações convergiam para novamente voltarem a se refletir.

Para o autor, as metáforas então definiam o espaço poético da linguagem - sua força criativa estava em um "conhecimento misturado e sem regra, onde todas as coisas do mundo se podiam aproximar ao acaso das experiências, das tradições ou das credulidades" (Ibidem, p. 70). Na era da linguagem encantada, como a chamaria Foucault, ela própria era signo das coisas e guardava vestígios daquilo que estava para além do homem.

No seu ser bruto e histórico do século XVI, a linguagem não é um sistema arbitrário [...]. A grande metáfora do livro que se abre, que se soletra e que se lê para conhecer a natureza não é mais que o reverso visível de uma outra transferência, muito mais profunda, que constrange a linguagem a residir do lado do mundo, em meio às plantas, às ervas, às pedras e aos animais. (Ibidem, p. 47-48)

O vigor dessa linguagem estaria em uma verdade primordial, que remontaria ao início dos tempos. A fórmula platônica, que se repetirá mais tarde na cosmologia judaico-cristã, diz que as palavras respondem a uma nomeação original vinda de Deus. "E aquelas palavras que Adão havia pronunciado, impondo-as aos animais, permaneceram, ao menos em parte, arrastando consigo na sua espessura, como um fragmento de saber silencioso, as propriedades imóveis dos seres". (Ibidem, p. 49-50)

Podemos dizer que, a partir de Descartes, funda-se um outro tipo de representação, agora como imagem mental. A ideia deixa de ser a forma da matéria, como em Platão e Aristóteles, e se torna conteúdo intrapsíquico: é verdadeiro tudo aquilo de que tenho consciência, máxima que ficou eternizada no cogito "penso logo existo". A passagem do eu penso ao eu sou é possível ao se articular representação e ser, sendo que, nesse caso, o ser se esgota na representação. 
Funda-se, então, o "teatro cartesiano", que consiste na atuação do ser humano como aquele que, de uma só vez, representa o mundo e é sua representação: ele é tanto espetáculo quanto espectador. A linguagem passa de coisa do mundo para signo transparente, pois sua função agora é servir de instrumento à consciência. A palavra é, nesse contexto, uma rede incolor a partir da qual os seres se manifestam em uma relação binária entre significante e significado. Ela é também o lugar onde as representações se ordenam, fazendo com que o saber empírico se sobreponha ao transcendental.

Já não é, portanto, o parentesco secreto entre as coisas que rege o funcionamento da linguagem. Esta ganha autonomia em relação ao mundo no momento em que se torna um sistema arbitrário de signos, criado pelo homem por um ato de conhecimento para auxiliá-lo em sua eterna busca pelo imutável, que, para os modernos, reduz-se a um elemento comum a todos os seres. Com Descartes, a semelhança é negada não em seu caráter comparativo, mas criador. As metáforas infinitas degeneram pouco a pouco em categorizações.

A busca por uma constante universal dispensa a aproximação das coisas em favor da análise de suas diferenças: procurase "obter pela intuição uma representação distinta das coisas e apreender claramente a passagem necessária de um elemento da série àquele que se lhe sucede imediatamente". (Ibidem, p. 76). Os signos como marcas de identidade e diferença perdem sua relação com o divino e convertem-se em instrumentos de análise - são princípios de ordenação, pontos de partida para uma taxionomia.

Se voltarmos nosso olhar à modernidade, não nos parecerá estranha uma ambição cara ao século XVIII, a de nomear cada ser vivo, encarnada na figura de Lineu, "quando ele projeta encontrar, em todos os domínios concretos da natureza ou da sociedade, as mesmas distribuições e a mesma ordem" (FOUCAULT, 2010, p. 105). Para tanto, era preciso demarcar a diferença entre a natureza humana e a animal. Aquele, com a pura capacidade de representar todo o caos contido nesta. Pela percepção - memória, imaginação e linguagem - a história descontínua da natureza seria organizada pelo homem.

A ciência, bem como a filosofia moderna, nas palavras de Jacques Derrida, retalhou os animais e lhes distribuiu porções de faculdades conforme o que lhe pedia sua "ingênua segurança". Por esse motivo, o autor coloca a filosofia como esse "esquecimento calculado" (DERRIDA, 2001, p. 28), já que enxergar o animal naquilo que ele tem de inapreensível nos "dá a ver o limite abissal do humano: o inumano ou o a-humano, os fins do homem, ou seja, a passagem das fronteiras a partir da qual o homem ousa se anunciar a si mesmo" (Ibidem, p. 31). 
Assim, de certa forma, a moral universal funda-se em uma alteridade negativa. É-se o negativo da negatividade que se inventou. Com efeito, o ato de nomear os outros animais, de reconhecê-los pela linguagem, permitiu ao ser humano definir-se a si próprio. Jacques Derrida nos lembra que o tema da nomeação remonta aos mitos fundadores da tradição ocidental, estando presente na mitologia grega, na gênese cristã e na filosofia iluminista. “Tal seria a lei de uma lógica imperturbável, ao mesmo tempo prometéica e adâmica, ao mesmo tempo grega e abraâmica (judeu-cristã-islâmica). Não cessaríamos de verificar sua invariância até nossa modernidade." (Ibidem, p.44)

Derrida fala, assim, de uma "limitrofia" da qual padece o homem moderno, já que ele é aquele "que se avizinha dos limites mas também o que alimenta, se alimenta, se mantém, se cria e se educa, se cultiva nas margens do limite" (Ibidem, p. 57), cuja "miopia" se exemplifica pelo próprio vocábulo "animal", que reúne em um termo homogeneizante a imensa variedade de seres existentes. Por esse motivo, o filósofo esgarça a linguagem comum "para combater a homogeneização de diversas espécies de bichos numa designação demasiado geral, com o seu neologismo 'animot'" (GLENADEL, 2008, p. 264). Para o pensador, todos os filósofos, apesar de discordarem do ponto em que se dava, acreditaram que o limite entre homem e animal era sempre único.

De um lado dessa linha, "um imenso grupo, um só conjunto fundamentalmente homogêneo que se tinha o direito, o direito teórico ou filosófico, de distinguir ou de opor, ou seja, aquele do Animal em geral, do animal no singular genérico. Todo o reino animal com exceção do homem" (DERRIDA, 2001, p. 76). E do outro, o eu cartesiano - que pensa, representa, nomeia e classifica, logo existe "(o homem como 'animal racional', o homem como animal político, como animal falante, zoon logon ekhon, o homem que diz 'eu' e se toma pelo sujeito da frase que ele profere então a respeito do dito animal etc.)" (Ibidem, p. 61).

Outro filósofo citado por Derrida que pensa a divisão entre homem e animal é Walter Benjamin, para quem ser nomeado é deixar-se invadir pela tristeza decorrente da passividade do ato e da impossibilidade de ir contra tal apropriação. "Luto pressentido, pois parece-me tratar-se, como em toda nominação, da notícia de uma morte por vir segundo a sobrevivência do espectro, a longevidade do nome que sobrevive ao portador do nome." (Ibidem, p. 42) Falta duplamente grave se inserida em uma linguagem metaforicamente estéril, em que o nome sobrevive não só ao portador, como a qualquer manifestação poética a ele vinculado.

Devido à nossa "limitrofia", que liga a concepção que temos de nós mesmos aos animais, revitalizar as metáforas feitas a partir deles é uma nova oportunidade de repensar - e talvez 
de expandir - as fronteiras humanas. Reviver uma metáfora pode significar desmontar um conceito, torná-lo livre para novas conexões. Segundo Armelle Le Bras-Chopard, é preciso desmontar o mecanismo de reflexão sobre o animal e o dispositivo de representações metafóricas, "a fim de desobstruir a função ideológica do referente animal: aquela que, ao justificar a sujeição dos bichos, que já é contestável, permitirá justificar a dominação sobre os seres humanos." (Ibidem, p. 21)

Mas como libertar uma metáfora de seu referente puramente humano e dar voz ao animal, mesmo aquele que existe dentro de nós? Para Derrida, toda nossa tradição investiu na noção de que "o pensamento do animal, se pensamento houver, cabe à poesia" (DERRIDA, 2001, p. 22), criando uma linha divisória não só entre homem e animal como entre pensamento filosófico e poético. A própria escrita de Derrida, no entanto, é um misto dessas duas esferas:

O texto derridiano conjura a poesia, no desdobramento semântico dessa palavra: entre invocação e exorcismo. Pois, afinal, apesar de suas afinidades com a poesia, esse texto não deixa de se inscrever naquilo que a tradição ocidental denomina discurso filosófico. O texto de Derrida se desdobra no lugar de uma impossível identificação, de uma impossível separação entre filosofia e poesia. (GLENADEL, 2000, p. 188-189)

O animal, "este vivente insubstituível" tem "uma existência rebelde a todo conceito" (DERRIDA, 2001, p. 26), escapando, pois, da área de atuação da filosofia no seu sentido convencional, que gira em torno das categorizações, de uma taxionomia erigida a partir de conceitos fixos e universais. O terreno literário por si só não garante, todavia, um discurso para além do humano, ele pode ser, bem como a fábula, "um amansamento antropomórfico, um assujeitamento moralizador, uma domesticação. Sempre um discurso do homem; sobre o homem; efetivamente sobre a animalidade do homem, mas para o homem, e no homem" (Ibidem, p. 68-69).

Trata-se, na verdade, de romper com a "limitrofia", que está presente em toda divisão, inclusive naquela que separa poema de filosofema - pensar o limite no que ele tem de abissal, e não no que ele tem de divisível. "Não se trataria de 'restituir a palavra' aos animais mas talvez de aceder a um pensamento, mesmo que seja quimérico ou fabuloso, que pense de outra maneira a ausência do nome ou da palavra, e de outra maneira que uma privação." (Ibidem, p. 89)

Para Jacques Derrida, a "poesia só consegue escapar da 'doença' ocidental tornando-se teatro" (DERRIDA, 1995, p. 159). E qual seria tal doença? Decerto a representação metafísica, tendo em vista que a citação derridiana pertence a um texto sobre Antonin Artaud e seu teatro da crueldade. Para este, o texto está para o teatro como o homem está para a vida: excessivo, usurpador. 
Artaud propõe, então, deixar de lado o narcisismo a partir do qual fundamos toda cultura em prol de uma abertura para o outro. É uma proposta ética que toca os limites da representação.

Em O animal que logo sou, Derrida nos diz haver uma história dos limites, macro e microscópica, história que talvez Foucault nos apresente em As palavras e as coisas. Já pudemos acompanhar mais detidamente dois dos seus momentos: aquele em que a linguagem pertencia ao mundo, depois quando ela se torna instrumento da consciência, e agora dedicar-nos-emos ao terceiro, quando ela aparece como a própria opacidade do ser. Para autores como Derrida e Artaud, nem o ser em geral está contido no pensamento, nem o ser singular foi por ele interrogado. É preciso sair da forma de pensar a qual fomos determinados, e expor o modo como ela funciona.

Em uma reflexão sobre o nascimento da noção de perspectiva para a contemporaneidade, Paulo Vaz coloca que "o constante questionamento talvez seja o nosso caminho de não mais reconstituir uma tradição que impede que o contato com outras formas de vida e com outras formas de viver seja um modo de nos experimentarmos diferentemente." (VAZ, 2011, p. 10) A tradição aparece aqui como uma "ameaça a um modo de vida que se deseja fixado" (idem).

A liberdade, portanto, está em romper com o estático, questionar os limites - mas a representação não suporta a relação com o inapreensível. A crise ontológica instalada a partir de então funda uma nova ética: é preciso abrir-nos a outros desejos, ao invés de apossarmo-nos daquilo que nos determina. Interrogar o pensamento na dimensão em que ele escapa a si mesmo, tarefa que muitos de nossos poetas e escritores vêm cumprindo transgressivamente desde a sistematização da linguagem como signo arbitrário.

Ora, ao longo de todo o século XIX e até nossos dias ainda de Hölderlin a Mallarmé, a Antonin Artaud - a literatura só existiu em sua autonomia, só se desprendeu de qualquer outra linguagem, por um corte profundo, na medida em que constituiu uma espécie de "contradiscurso" e remontou assim da função representativa ou significante da linguagem àquele ser bruto esquecido desde o século XVI. (FOUCAULT, 2010, p. 60)

A linguagem encantada não foi, entretanto, de todo reconstituída por essa nova experiência poética, pois temos agora no lugar da origem divina uma outra força motriz, o originário. Embora aparentadas etimologicamente, origem e originário são conceitos distantes. $\mathrm{O}$ primeiro se refere a um ponto inicial, o começo da história, ao passo que o segundo se dá quando percebemos a história como construção. "Representação como re-apresentação da origem estável, segura e fixa nalgum lugar, e representação como impossibilidade de recuperação da origem simples, como apresentação da dupla 
fonte, como des-apresentação, em suma" (NASCIMENTO, 1999, p. 69), eis a distância existente entre os dois conceitos enquanto a origem nos oferece uma representação do mundo pontual e regular, o originário nos dá aquilo que ele tem de absolutamente vertiginoso.

"Fim da representação mas representação originária, fim da interpretação mas interpretação originária que nenhuma palavra dominadora, nenhum projeto de domínio terá investido e previamente pisado." (DERRIDA, 1995, p. 158) Artaud conclama a apresentação do sensível em si, do físico sem uma meta, para que se possa enfim superar a limitrofia humana de que sofre o teatro metafísico, já que a vida é a origem não representável da representação. "O teatro da crueldade não é uma representação. É a própria vida no que ela tem de irrepresentável." (Ibidem, p. 152)

Esse teatro deve então superar o humano, e portanto o logocentrismo e sua primazia da escrita e da voz, para igualar-se à vida - "quando pronunciamos a palavra vida, deve-se entender que não se trata da vida reconhecida pelo exterior dos fatos, mas dessa espécie de centro frágil e turbulento que as formas não alcançam" (ARTAUD, p. 8) -, sem reportar-se a uma origem divina ou a uma presença primeira. Logo, romper com as narrativas causais protagonizadas pelo homem, que buscam incessantemente dar sentido ao inesperado.

Para o devir ser livre, ele não pode ser determinado pelo passado, o que levaria a um predomínio da vontade sobre o corpo. Essa é a regra moral e teológica da qual Artaud quer livrar o teatro. Ele busca uma linguagem carnal, em detrimento daquela que se propõe a ser o veículo de uma interioridade: ultrapassar as ideias eternas, que se corrompem ao atingir o sensível, para explorar as que tenham a força da fome. "Acima de tudo precisamos viver e acreditar no que nos faz viver e em que alguma coisa nos faz viver - e aquilo que sai do interior misterioso de nós mesmos não deve perpetuamente voltar sobre nós mesmos numa preocupação grosseiramente digestiva." (Ibidem, p. 1-2)

E por vivermos em uma sociedade ruminante e sem apetites que o teatro pede a crueldade: o embrutecimento do pensar ao qual chegamos só pode ser quebrado pela vida em toda sua crueza. A crueldade seria esse movimento do originário, que vai contra o uso metafísico da linguagem, capaz, por sua vez, de esvaziar as consequências extremas e poéticas da palavra. "A Arte não é a imitação da vida, mas a vida é a imitação de um princípio transcendente com o qual a arte nos volta a pôr em comunicação" (ARTAUD apud DERRIDA, 1995, p. 152-153)

Ao contrário da tradição teatral, o palco deve ser o lugar da destruição da mimesis, uma vez que essa estrutura representativa dá lugar ao discurso teológico, que não necessariamente é religioso, mas "dominado pela palavra, por uma vontade de palavra, pelo objetivo de um logos primeiro que, não pertencendo ao 
É interessante notar que, embora Derrida e Novarina sustentem uma posição, em um primeiro momento, oposta àquela de Artaud em relação à escrita, os três autores chegam, cada um a seu modo, em um ponto de convergência que seria a crítica a uma "metafísica da escrita fonética", nas palavras de Derrida, em De la grammatologie (DERRIDA, 1967, p. 11). Nesse panorama comum, a linguagem não corresponde a uma ordenação, cujo objetivo é a busca pela verdade geral, mas a uma ultrapassagem dos obstáculos técnicos, epistemológicos, teológicos e metafísicos, em um projeto inapreensível, pois jamais único - seja, como o quer Artaud, por uma voz que se desvincule da escrita, ou como o fazem os outros dois pensadores, por uma escrita desvinculada da voz. Desse modo, mesmo valorizando a escritura, esfera execrada por Artaud, tanto Derrida quanto Novarina conseguem reverenciar a crueldade artaudiana. Essa semelhança entre os três autores franceses permeará, de certa forma, a parte final de nosso artigo. lugar teatral, governa-o à distância." (DERRIDA, 1995, p. 154) A representação imitativa segue invariavelmente um sentido elementar, fundado pelo autor-criador, que rege os atores como marionetes, mantendo com o real uma relação reprodutiva e não criadora. Se o palco não é lugar para a criação, tampouco o é a audiência. O público desenvolve com o espetáculo uma relação passiva e pouco provocativa.

Nesse cenário, para Artaud, a voz se dá como origem e a escrita como prótese. ${ }^{1}$ Assim, a voz aparece como expressão da verdade, uma interioridade inquestionável, uma essência. A escrita que a acompanha não é então problemática apenas pelo afastamento em relação à atuação, ao instante, em suma, pela palavra presa ao papel, mas o é enquanto uma escrita que se quer representante dessa voz, ditada pelo divino. "A restauração da divina crueldade passa portanto pelo assassínio de Deus, isto é, em primeiro lugar do homem-Deus."(Ibidem, p. 166)

Derrida nos mostra que a palavra e a escrita fonética enquanto instrumentos a serviço do pensamento, cujo único destino é a representação seguida de contemplação, devem ser expulsas do palco de um teatro cruel - entendido aqui como teatro da vida -, porque são, a um só tempo, citações e ordens: eles buscam transmitir um conteúdo, "dando a ler o sentido de um discurso a auditores, não se esgotando totalmente com o ato e o tempo presente da cena, não se confundindo com ela, podendo ser repetido sem ela" (DERRIDA, 1995, p. 170). A cena não pode, portanto, apenas repetir um texto cuja origem está fora de si. Ela não pode repetir um presente, já que assim perpetua a presença dessa voz centrada no logos, em Deus, no homem, e não na vida.

A representação originária identifica-se enfim com a não representação, cujo tempo transgride aquele da linearidade fônica, seguindo antes a ordem do paradoxo (vida e morte, diferença e repetição originária). É uma dialética que ao invés de buscar uma síntese, vai radicalmente na direção da contradição. Na dialética hegeliana, temos um jogo de dados viciados, cuja vitória, a partir da síntese, pende sempre mesmo para um mesmo lado, pois o logos não se abre ao paradoxo. Na dialética artaudiana, temos um jogo cujo interesse não se dá no resultado, mas na disputa.

Como no "lance de dados" mallarmeano, a disseminação torna-se o movimento gerador da escrita e orientador da leitura. Dispersão feita a partir de um foco ou núcleo primitivo, mas dispersão incontrolável, impossível de ser reunida, reunificada, indefinidamente prometida ao fluxo e à deriva. (GLENADEL, 2000, p. 191-192)

Nesse jogo, a palavra e a escrita voltarão a ser gestos, guardiões da intensidade fulgurante em uma imitação primeira daquilo que fora então criado, escapando da monotonia repeti- 
tiva do signo. "Não se trata portanto de construir uma cena muda mas uma cena cujo clamor ainda não se apaziguou na palavra" (Ibidem, p. 161), nem mesmo em uma relação negativa com ela, o que leva à rejeição da limitrofia humana e ao crescimento em número e espessura das fronteiras da representação.

Como será então a gramática de um tal teatro? Derrida nos responde: ela estará sempre por encontrar, pois é "o inacessível limite de uma representação que não seja representação, duma representação que seja presença plena, que não carregue em si o seu duplo como a sua morte, de um presente que não se repete" (Ibidem, p. 173). Ainda assim, o teatro da crueldade não é um plano futuro, mas uma impossibilidade que opera continuamente no vazio deixado pelo teatro metafísico. "O vazio, o lugar vazio e pronto para esse teatro que ainda não 'começou a existir', mede portanto apenas a distância estranha que nos separa da necessidade inelutável, da obra presente (ou melhor atual, ativa) da afirmação". (Ibidem, p. 151)

A obra de Valère Novarina localiza-se também em um tal vazio. Segundo Clément Rosset, ela é a expressão de uma doença (un malaise ou un malêtre), de uma crise metafísica permanente, o que não significa situá-la em uma linguagem negativa, retrátil. Ao contrário, o teatro novariniano tende a crescer infinitamente nesse vácuo. "Quanto menos ele tem a dizer, mais Novarina encontra (e inventa) palavras para dizer. [...] Apresenta uma surpreendente vitalidade, ainda que seja, para retomar sua própria expressão, uma 'vida apesar de si'". ${ }^{2}$ (ROSSET, p. 60)

Assim como Artaud, Novarina vem se abrir à vida para além da limitrofia humana. O teatro das palavras ironicamente vai contra a tradição logocêntrica por dirigir-se antes às palavras do que aos homens, direcionamento que define desde a ontologia de suas peças até seu ritmo cênico: "a cena é uma sucessão de entradas (nascimentos) e de saídas (mortes) comandadas por uma enunciação em que o enunciador não tem absolutamente a paternidade" (TREMBLAY, 2008, p. 4).

Rosset complementa que a temática fundamental do teatro de Novarina é "o aspecto culposo e até 'criminal' da procriação que volta a transmitir, com a vida, o vírus da doença humana" (ROSSET, 2001, p. 59). Essa temática recorrente, segundo o autor, ganha uma nova pulsão com a escrita novariniana, cujo aspecto nuclear é a ausência de um sujeito enunciador e a forte presença

2 As citações dos livros que, na bibliografia, estão no original em francês foram traduzidas por mim. Os demais, cuja edição utilizada já está em português, conta, em sua referência bibliográfica, com o nome de seu respectivo tradutor. do verbo como alteridade. O corpo humano se fragiliza, exposto na sua efemeridade, ao passo que a língua ganha corpo.

"Na língua novariniana, nada desempenha um papel pré-definido, determinado e fixo, tal como constatamos em uma lógica representativa." (TREMBLAY, 2008, p. 14) Na sua fala polifônica, a linguagem se torna impessoal, pois não pertence a nenhum sujeito da enunciação, antes ela atravessa essas 
representações individuais, que estão longe do sujeito cartesiano acabado e livre de falhas. Tremblay fala de uma metonímia da boca - a parte pelo todo -, um orifício que desempenha o papel desse homem furado pela linguagem e pelo pensamento, que ao mesmo tempo morde o mundo ao falar.

"A fala apareceu um dia como um buraco no mundo feito pela boca humana - e o pensamento primeiro como uma cavidade, um golpe de vazio desferido contra a matéria. Nossa fala é um buraco no mundo." (NOVARINA, 2009, a, p. 15) Voltamos aqui às imagens intestinas caras a Artaud, às ideias famintas. Tremblay nos mostra que, no teatro novariniano, os personagens oscilam entre a superfície da fala e o ventre afamado:

Ao nascer o sujeito na língua, executa-se um salto definitivo para fora da animalidade, mesmo se a boca [...] pode ser responsável por uma regressão, cujas palavras retornam das profundezas do ventre, de onde emergem, na superfície, os gritos e a pulsão sonora de uma memória pré-linguística. (TREMBLAY, 2008, p. 12-13)

Tremblay nos mostra que a inversão da ordem imposta pela representação metafísica - indivíduo primeiro, linguagem a seguir - coloca em primeiro plano a carne, em suas próprias palavras o "cu em cima da cabeça" (NOVARINA, 2009, b, p. 14). Obviamente, uma tal inversão tem suas consequências na diegese novariniana, que acaba se distanciando da progressão narrativa. Como dissemos anteriormente, a narrativa causal é aquela centrada em uma interioridade, pois tem como principal função dar sentido a determinada existência. Se o grande ator desse ato são as próprias palavras, não fazem parte dele a linearidade e coerência tão caras à representação convencional.

É o fim do homem e o início da vida. "Joga-se, as coisas em um buraco, produz-se a morte para a morte, mas também 'para nascer'". (Ibidem, p. 19) O non-sense dos personagens, que beira a idiotia, é um sintoma dessa ausência de sentido causal, de coerência individual, que faz com que a trama, se é que existe alguma, comece com um "eu", mas dissolva-se sempre no impessoal. $\mathrm{O}$ embuste de um personagem com uma composição psicológica se revela sob alguns vestígios, como a ausência de uma história pessoal, ou até pelos nomes, absurdamente excêntricos ou simples ao extremo.

A despersonalização máxima se dá quando, no espaço da ficção, Novarina brinca com o limite da representação, mostrando que "a presença 'desnudada' dos atores sobre o tablado é apenas uma ilustração dentre as outras, mas bem eloquente" (TREMBLAY, 2008, p. 105). Assim, o ator André Marcon interpreta o Ator André Marcon, tornando quase imperceptível a linha que separa o teatro da vida. "O verdadeiro ator não nos devolve nossa imagem, não nos dá em troca nossa figura; ele não 
é imitador do homem. O teatro é um lugar que se edifica perante nós para revirar o ídolo humano." (NOVARINA, 2009, b, p. 24)

Depreendemos, a partir de então, que os longos monólogos novarinianos não seguem o egocentrismo humano, mas antes a impessoalidade da fala e a impossibilidade da representação. Para tanto, necessita-se de "uma destruição completa dos antigos automatismos: o Eu narrativo, a intriga, a representação, o drama burguês são então eliminados". (Ibidem, p. 91). Novarina, como Artaud, vê o teatro da perspectiva do seu fim: o fim da representação, da metafísica, da limitrofia humana.

Não à toa, a cena inicial de $O$ animal do tempo acontece em um cemitério. $\mathrm{O}$ seu ponto de partida são inscrições lapidares, resquícios do que os homens foram um dia, mas também devires, possibilidades do que podem vir a ser. "Eis a frase do homem de oito, João Penacho: 'Eu jazi, eu jazia, eu jazezia, eu já, já não jazi também, ó doce ser, volta para mim!' Mas ela não pode pois somos quem somos." (NOVARINA, 2007, p. 8) Logo a seguir, o túmulo do solitário apresenta as inscrições: " 'Conheci a morte só quando vivo; repouso agora nos braços da quarta pessoa do singular'. Assinado João do Homem, filho de fim, pseudoHenrique, garoto esplêndido vestido de nu e buraco esquerdo". (Ibidem, p. 8-9)

Fim e fome se confundem no texto novariniano (fin e faim), quando "a forma fala melhor do que o conteúdo" (TREMBLAY, 2008, p. 36), e as relações sintáticas e lexicais se misturam aos nomes. É desse modo que as palavras de Novarina escapam à função imitativa de uma metafísica, uma vez que a escritura, nesse caso, opõe-se à voz logocêntrica ao invés de segui-la. “Em primeiro lugar, anula-se a oposição interior/exterior, então nenhum pensamento, como um monólogo, é interiorizado, a fala é assim exclusivamente sonora." (Ibidem, p. 120-121)

O teatro das palavras busca, portanto, a palavra antes das palavras, uma escrita primeira, anterior ao homem, a partir de sua própria impossibilidade. Nesse cenário, as figuras de animalidade desempenham um papel fundamental, demarcando, ou antes, desmarcando o lugar designado ao homem entre as palavras e as coisas.

A proposta novariniana de ver "tudo por seus buracos animais" (NOVARINA, 2007, b, p. 14) leva-nos a repensar as fronteiras do homem hoje e a resgatar o papel da linguagem nesse processo. No teatro das palavras, estas deixam de ser trocadas como "fórmulas e slogans" (Ibidem, p. 13), para tornarem-se "oferendas e danças misteriosas" (Idem). Por mais que exista nesse movimento a completa desagregação da figura humana, ela continua sendo crucial na tarefa de pensar os limites da representação. Ao questionar a percepção mais corriqueira e superficial dos contornos do homem, Novarina instaura uma 
busca por aquilo que lhe é próprio: sua capacidade criativa de entrar "no mundo saindo" (Ibidem, p. 22).

A condição humana está para além do dado biológico, se por um lado ela é um fardo, por outro, deve ser conquistada, como convoca o seguinte trecho: “Oh, homem, filho de omnídios, complete aqui sua hominização, nós te suplicamos! e retome seu labor massivo para ser digno um dia de portar teu nome de homem tatuado por ti em escrita Ômnica e sobre tua fronte em caracteres antropofóricos." (NOVARINA, 2007, a, p. 38) A linguagem mecânica e instrumental predominante no "nosso Ocidente desorientado" (NOVARINA, 2009, a, p. 14) faz perder essa dimensão essencial do homem fundada pela palavra:

Eis que agora os homens trocam entre si palavras como se fossem ídolos invisíveis, forjando nelas apenas uma moeda: acabaremos um dia mudos de tanto comunicar; nos tornaremos enfim iguais aos animais, pois os animais nunca falaram mas sempre comunicaram muito-muito bem. Só o mistério de falar nos separava deles. No final, nos tornaremos animais: domados pelas imagens, emburrecidos pela troca de tudo, regredidos a comedores do mundo e a matéria para a morte. (Ibidem, p. 14)

O teatro de Novarina insere-se, pois, naquele momento da história do saber marcado em sua relação com a linguagem pelo resgate de alguns aspectos anteriores à idade clássica, quando o signo jazia sobre as coisas, e pelo rompimento com aquele imediatamente após, em que prevalecia a razão instrumental. As obras novarinianas como um todo situam-se nesse "caminho do meio", uma "reflexão reflexiva", em que o próprio pensar é posto em xeque.

Um dos principais aspectos questionados pelo escritor francês é a produção de sentido, esse "imundo folhetim" (NOVARINA, 2007, b, p. 20), continuamente demandada pelo teatro metafísico. Em sua escritura, o teatrólogo não apenas rompe com a coerência narrativa, como brinca com a necessidade que temos dela. Segundo Tremblay, "a linearidade sempre encoraja o sentido, ainda que ele seja indeterminado" (TREMBLAY, 2008, p. 35).

O animal do tempo, como o próprio título anuncia, é uma peça em que se coloca principalmente em questão a representação que o homem faz de si, ressaltando de antemão o aspecto fundador da humanidade - o tempo, evidente em qualquer construção linguística, fundador da nossa noção de finitude e de linearidade. $\mathrm{O}$ tempo que desenvolve conosco uma relação causal, que nos amarra em sua estaca, e nos torna animais com passado, animais repetitivos, animais com memória, animais que prometem. Animais, enfim, que se separam dos demais, e vivem apenas nas vizinhanças do seu limite. 
A peça é a estranha biografia de ninguém, de um João sem Objeto e também sem Sujeito: "o cérebro branco que desprezou tudo o que ele pensou" (Ibidem, p. 11). Seu julgamento e libertação, não necessariamente nesta ordem. É um testemunho vazio, mas pleno de vida, pois parte de alguém que já se retirou da linguagem, ou antes, de alguém que responde ao vago chamado desta: um "João sem ações" (Ibidem, p. 12), que não sabe contar sua entrada solene na vida, pois dela só conhece as saídas.

Eis animais, a história verídica e sem cabeça nem pé, de um homem de mim que um dia de junho de cinquenta e sete e seis, nasçu em Annamassa ou em Bulgato e que se lembra de nada do mundo de antes-depois a não ser que se estava na véspera do dia no qual saí vivo ajambrado com um velho crânio. (Ibidem, p. 29)

Seu narrador é ao mesmo tempo uno e múltiplo, todos e nenhum: "objeto de objeto, carregador estúltico, coberto de penas epaminais, doente do tempo, desaparecendo, sem sujeito $n u^{\prime \prime}$ (ibidem, p. 17, grifos meus). Seu nome é João. João Trinta e Seis Mil, João Grande Caim, João Penacho, João Lânguido, João do Homem, João Post-Scriptum, João Maquinal, João Nada que Vem, João que entra saindo, João o Passador Sai quando ele Vem. Ele é um João sem nome, um homem anterior à nomeação: "João da carne de vida e sem espírito" (Ibidem, p. 18), cumprindo um papel libertador, quiçá sagrado: “'Benditos sejam os que são sem nome."' (Ibidem, p. 10)

O divino aqui não é dar, atribuir, mas antes arrancar o homem de sua limitrofia - apagar todas as divisões, ou talvez multiplicá-las ao infinito, de modo que o conhecimento trazido pela linguagem se liberte das restrições impostas pelo racionalismo. Se o sacrifício humano destrói em um nível, em outro, ele devolve à linguagem a dimensão do sagrado, pois vai além do utilitarismo. "Tira o buraco de dentro de você e dá, pois Eu sou. Então, eu lhe escrevi: Deus, se tu és deus, não mostres: tira tudo!" (Ibidem, p. 10) O sacrifício humano consiste, portanto, não no retorno à origem da linguagem, mas ao seu originário. "A cada página ou meia página, o ritmo deve passar por seu colapso. A linguagem é tátil como se fosse a verdadeira matéria: um fluido fora dos homens, os afetando." (NOVARINA, 2009, b, p. 11-12)

Essa linguagem tátil que se faz matéria tem ela própria uma materialidade. Novarina esgarça os limites da linguagem para falar o indizível ou para calar o que já está dito. "Abre-se aqui um lugar filosófico híbrido, atravessado pela escrita poética." (GLENADEL, 2000, p. 192) Uma de suas estratégias mais frequentes para tanto é a glossopoiese, termo derridiano, referente ao teatro de Artaud, que "não é nem uma linguagem imitativa nem uma criação de nomes, reconduz-nos à beira do momento em que a palavra ainda não nasceu, em que a articulação não 
mais é grito mas ainda não é discurso, em que a repetição é quase impossível" (DERRIDA, 1995, p. 161).

A glossopoeiese novariniana guarda ainda um artifício a mais, um efeito cômico, que dá ao autor um estilo próprio. Como observou Tremblay, tal produção baseia-se principalmente no deslocamento de unidades lexicais. "Por exemplo, em relação aos substantivos, a lista pode incorporar uma palavra estrangeira como 'houe' (um tipo de picareta) atravessando nomes de pássaros mais ou menos verídicos." (TREMBLAY, p. 34) A combinação feita é, em geral, fácil de se notar, pois obedece a uma lógica interna, que logo se apresenta ao leitor. Amnimais, omnimais, umnimanos, omnimianos, anaimais, haniaimais. Animais e homens misturam-se, confundem-se, desordenam os limites ao mesmo tempo em que nos fazem rir pela ilogicidade da junção: "a coisa mesma respira em verdade e o espetáculo torna-se um animal com sua vida" (NOVARINA, 2009, b, p. 63).

Para Novarina, o cômico não é algo superficial, como geralmente se crê, um tipo de diversão. "Ele vai ao mais profundo da língua, no seu abismo (seu sem fundo) de destruições e reconstruções: faz eclodir uma energia atordoante" (NOVARINA, 2009, b, p. 25). Debochando, o autor instaura ao redor das antigas palavras uma nova vivacidade, de modo que "a palavra, que por ela mesma não quer dizer nada, sugere uma nebulosidade de significações pela riqueza de suas 'harmônicas', como se diria de um acorde musical bizarro e polissêmico" (ROSSET, 2001, p. 61).

Outra estratégia é a desorganização sintática da frase, que faz com que o objeto não se submeta ao sujeito, nem mesmo dentro da oração. Vemos assim desencontros de gênero, número ou grau: "Esse canção bêbado três vezes soltado, eu o derramou na minha cabeça ad libitum como um canção que deu errado." (NOVARINA, 2007, b, p. 28); "discordâncias" verbais: "Eu venceu o medo [...]." (Ibidem, p. 29); intransividade do transitivo: "No dia seguinte ao incidente, fui ver um médico pra lhe perguntar se eu era. Sem que ele confirmasse essa impressão." (Ibidem, p. 11).

A busca por essa escrita originária, por "descer na linguagem como em uma matéria profunda do tempo e na arquitetura do ato" (NOVARINA, 2009, b, p. 10), mostra que Novarina inserese naquele terceiro momento epistemológico, cuja relação com a linguagem prevê sua anterioridade ao homem, não apenas a ele revelando o mundo, mas também o determinando. "As palavras preexistem ao teu nascimento. [...] Nem instrumentos nem utensílios, as palavras são a verdadeira carne humana e uma espécie de corpo do pensamento: a fala nos é mais interior do que todos os nossos órgãos de dentro." (NOVARINA, 2007, b, p. 14)

Essa fala impessoal parece ela própria denunciar a cisão entre o signo e o mundo vivenciada pela modernidade: "Animais de cérebro, olhem a inscrição: eles gravaram seus túmulos em soalhos. 'Aqui repousa o homem sem as coisas: tudo é 
sem mim.' (Ibidem, p. 7). Para o autor, a "luz do mundo é sem razão" (ibidem, p. 7), do que deduzimos que com o pensamento instrumental "tudo está no mundo, menos eu" (Ibidem, p. 13). Novarina não se dedica, entretanto, à crítica pura ao racionalismo, tampouco ao resgate total da linguagem encantada. "Eu me tornei sem saber aquele que dorme agora entre a voz sem a razão e os sons da reprodução do mundo pelos sons" (NOVARINA, 2007, a, p. 17).

Assim, ambas as esferas estão implicadas nessa nova noção de mundo. Se por um lado, ele considera que a linguagem, ainda que seja a teatral, exponha "o elo contínuo, o continuum entre linguagem e matéria" (NOVARINA, 2009, b, p. 51), por outro, afirma que as "palavras não vêm mostrar coisas, dar-lhes lugar, agradecer-lhes educadamente por estarem aqui, mas antes partilas e derrubá-las". (NOVARINA, 2007, a, p. 14-15) É a opacidade de uma linguagem anterior ao homem. Sendo assim, ela mesma o leva a questionar a propriedade daquilo que ele pensa, fala e escreve. "'Tudo o que escreve o homem pelo homem é um falso, inclusive até essa inscrição."' (NOVARINA, 2007, b, p. 8)

Resta-nos, portanto, viver no limite. Não cerceados por ele, mas equilibrados como se atravessássemos um abismo sobre uma corda-bamba. Retomar as fronteiras do homem, encenando, desta vez, o obsceno. "O ato do teatro dá a fala aos mudos: aos objetos - e não somente aos humanos que se calam." (NOVARINA, 2009, b, p. 47) Novarina revive, pois, quimericamente os objetos outrora assujeitados pelo fonocentrismo, pelo logocentrismo, pelo antropocentrismo, e por tantos outros "ismos" centrados na razão, especialmente os animais, afinal, a linguagem originária buscada por ele é anterior à divisão entre o humano e o não humano.

"A origem do teatro, tal como a devemos restaurar, é a mão levantada contra o detentor abusivo do logos, contra o pai, contra o Deus de um palco submetido ao poder da palavra e do texto." (DERRIDA, 1995, p. 159) Novarina sabe que o movimento recorrente da linguagem nos últimos séculos tem sido de segregação. "E do meu pai sou filho único." (NOVARINA, 2007, b, p. 22) Mas ainda assim questiona tal separação: "Por que estou sozinho na natureza sem sete milhares de bichos semelhantes?" (Ibidem, p. 15)

O homem de um lado, sozinho, superior, e os animais do outro, todos os animais, subjugados, pelas palavras, em sua existência. "O que você estudou? Estudei a solidão. Animais, animais, cada vez que eu vi um outro eu me vi a mim mesmo em pior." (Ibidem, p. 12) Novarina busca assim um eu que não mais se instaure contra o outro. "Pensamento, se você não fosse aquele que odeia você não seria aquele sou." (Ibidem, p.11) O autor brinca aqui com a sonoridade dos verbos odiar e ser, em francês, hait e est, similares na conjugação do tempo presente. 
Ser é odiar, talvez por isso o melhor seja não ser. Ou ser todos simultaneamente. "Hoje, João que é, eu não distingo nenhum dia de sua véspera, nem um objeto de objeto, nenhum outrem de um outro, nem separo o animal do omnimal nem o nada do meu." (Ibidem, p. 16) A fauna novariniana não deixa de ser cantada pelo homem, mas agora o homem é cantado pela linguagem, ao invés de quedar-se preso à "imunda repetição". (NOVARINA, 2007, a, p. 20) Novarina conclui $O$ animal do tempo com a nomeação de mais de cem pássaros: "limnota, a fugia, a hipília, o escalário, o ventisco, o luro, o figilo, o lepândrio, a galupa, o encreto, o furista, o Tião, o narcilo, o áulico, a gimnestra, a lousa, o drânglio, o fugilo, o ginel, o tripa, o semelico, o lipodo, o hipiando" (ibidem, p. 31), e por aí vai. Os pássaros novarinianos cessam de "respirar re-cada vez numa sílaba re-já dita" (NOVARINA, 2007, b, p. 20-21) e nos fazer voar para além da linguagem e para fora do tempo.

\begin{abstract}
This article is dedicated to the discussion launched by Valère Novarina about man's limits and possibilities, understanding his theater as the performing of the language and of the human. The dense metaphors, created under the "animal mask", contribute to form the conflict between the man and the world. Performing the animal, in this context, does not mean, therefore, turn the stage into an imitation or representation space, but into a questioning one. Novarina review, thus, an entire metaphysical tradition, present in the theater, but also in our thoughts. We should do the same, if we are to understand the scope of his writing and its poetic and philosophical implications. Time's animal is the work from which we will make such an analysis.
\end{abstract}

Keywords: Novarina; representation; theater; animalism; metaphysics.

\title{
REFERÊNCIAS
}

ARTAUD, Antonin. O teatro e seu duplo. Trad. Teixeira Coelho. São Paulo: Martins Fontes, 1999.

BAUDRILLARD, Jean. Os Animais. Território e metamorfoses. In: . Simulacros e Simulação. Trad. Maria João da Costa Pereira. Lisboa: Relógio d'Água, 1991.

DERRIDA, Jacques. A escritura e a diferença. Trad. Maria Beatriz Marques Nizza da Silva. São Paulo: Editora Perspectiva, 1995. . De la grammatologie. Paris: Les Éditions de Minuit, 1967. 
. O animal que logo sou. Trad. Fábio Landa. São Paulo: Editora UNESP, 2002.

FOUCAULT, Michel. As palavras e as coisas. Trad. Salma Tannus Muchail. São Paulo: Martins Fontes, 2010.

GLENADEL, Paula. Derrida e os poetas: de margens e marcas. In: NASCIMENTO, Evando e GLENADEL, Paula (Orgs.). Em torno de Jacques Derrida. Rio de Janeiro: 7letras, 2000.

. O Corpo da Letra: Símios e Moscas em Jacques Dupin. In: PEDROSA, Célia e ALVES, Ida (Orgs.). Subjetividades em Devir - Estudos de poesia moderna e contemporânea. Rio de Janeiro: Editora 7 Letras, 2008.

LE BRAS-CHOPARD, Armelle. Le Zoo des Philosophes. De la bestialisation à l'exclusion. Paris: Plon, 2000.

NASCIMENTO, Evando. Derrida e a literatura. Niterói: EdUFF, 1999.

NOVARINA, Valère. Diante da palavra. Trad. Ângela Leite Lopes. Rio de Janeiro: 7Letras, 2009, a. . L'Acte inconnu. Paris: P.O.L éditeur, 2007, a. . L'Envers de l'esprit. Paris: P.O.L., 2009, b.

. O animal do tempo. A inquietude. Trad. Ângela Leite Lopes. Rio de Janeiro: 7letras, 2007, $b$.

ROSSET, Clément. Le régime des passions et autres textes. Paris: Les Éditions de Minuit, 2001.

TREMBLAY, Nicolas. Le théâtre et l'origine dans l'oeuvre de Valère Novarina. Abril de 2008. 197 f. Tese (Doutorado em Estudos Literários) - Université du Québec à Montréal, Montréal.

VAZ, Paulo. O sentido do ceticismo. Disponível em: http://www. oquenosfazpensar.com

/adm/uploads/artigo/o_sentido_do_ceticismo/n8paulo.pdf. Acessado em: 30 mar. 2011. 